\title{
Prevalence and Risk Factors of Strongyloides Stercoralis Infection in Selected Tea Garden of Sylhet, Bangladesh
}

Muhammed Hossain ${ }^{*}$, Md. Shafiul Alam², Maisha Khair ${ }^{2}$, Md. Abu Sayeed ${ }^{3}$ and Md. Jamal Uddin Bhuiyan

${ }^{1}$ Department of Parasitology, Faculty of Veterinary and Animal Sciences, Sylhet Agricultural University, Sylhet-3100, Bangladesh

${ }^{2}$ Parasitology Research Group, Center for Communicable Diseases, International Center for Diarrhoeal Disease Research, Bangladesh

${ }^{3}$ Department of Epidemiology and Public Health, Faculty of Veterinary and Animal Sciences, Sylhet Agricultural University, Sylhet-3100, Bangladesh

\begin{abstract}
Background: Strongyloidiasis infection is partially an asymptomatic infection and the diagnosis of patent infection is difficult using conventional parasitological methods. The residents of tea garden community of Sylhet, Bangladesh were robustly tested.
\end{abstract}

Method: The collected stool samples were tested by Harada mori culture for the presence of larval stage of Strongyloides stercoralis and to reaffirm the same samples were subjected for conventional PCR, using primer sets deigned to amplify partial ribosomal DNA of S. stercoralis genome. Finally data analysis was performed by Logistic Regression procedure using STATA 13 (College Station, Texas 77845 USA) and Pearson $\lambda^{2}$ test, with consideration of $\mathrm{P}<0.05$ as an indication of significant.

Result: A total of 300 stool samples freshly collected and examined among those $18(06.00 \%)$ samples were found positive for S. stercoralis in Harada mori culture. In amplification of DNA extracted from raw samples and culture fluid of positive sample, the conventional PCR detected S. stercoralis $38(12.67 \%)$ positive. There were 6 samples positive in Harada mori culture but did not show any response in sophisticated PCR techniques it might be due to low burden of infection. Periodic anthelmintic does not taking $\mathrm{OR}=3.946(95 \% \mathrm{Cl}$ 1.369-11.375; $\mathrm{P}=0.011)$ and does not wash feet coming from out $\mathrm{OR}=5.158(95 \% \mathrm{Cl} 1.656-16.068 ; \mathrm{P}=0.005)$ significantly associated with Strongyloidiases infection.

Conclusion: This study confirmed that $\mathrm{S}$. stercoralis is prevalent in the tea garden community of Sylhet identified by both parasitological and molecular methods. The preventive measures by deworming are warranted. Public health education regarding properly periodic anthelmintic taking, wash feet coming from out and personal hygiene are also additional required elements.

Keywords: Strongyloides stercoralis; Prevalence; Risk factors; Harada mori culture; PCR

\section{Introduction}

The threadworm Strongyloides stercoralis is a common intestinal nematode affects 30-100 million people worldwide [1,2]. S. stercoralis is only parasite of soil transmitted helminths (STH) group which can cause auto infection and thus ultimately lead to high parasite intensity specifically in immune-compromised individuals [3-5]. Strongyloidiasis is endemic in areas where sanitation conditions are poor and where the milieu is warm and humid [6] such as Asia, Africa, Southeast Asia, Bangladesh, Central and South America [79]. Coprological and recent serological serological studies, in slum areas of Dhaka, ensured its continued existence in Bangladesh $[6,10]$. Severe complication with clumsy infection of strongyloidiasis may lead to substantial mortality as high as $87 \%$ [8]. Paucity of information is available on prevalence of $S$. stercoralis infection on most of these setting [11]. Confirmation of Strongyloides infection by coproglogical examination is difficult because of irregular excretion of the parasite especially in chronic cases; prevalence of infection thus underestimated $[9,12]$. Widely used diagnostic procedures, such as direct fecal smear, Baermann technique and Koga agar plate are not satisfactory when used in single stool samples [13,14]. The detection of larvae of Stgongyloides in the stool is an evidence of infection [8]. The diagnostic methods such as direct fecal smear, Harada mori culture $[15,16]$ have been used to detect larvae in stool but the exact sensitivity of these diagnostic approaches is debated [17]. Most of the infections may remain asymptomatic [18-20] but diarrhea and abdominal pain are the most common symptoms $[21,22]$. The common dermatological aspects of chronic strongyloidiasis are itching and rash [23]. There is scarcity of information on S. stercoralis infection in rural setting of tea garden community though few work available in Dhaka slum [10, 24]. The objectives of this study conducted in tea garden community of Sylhet to ascertain the prevalence and plausible determinants for strongyloidiasis including socio demographic and household factors based on Harada mori culture and molecular techniques.

\section{Materials and Methods}

\section{Study area}

The study areas of Sylhet district located $315 \mathrm{~km}$ south east from capital city Dhaka were selected for this study as it is the poorest area of Bangladesh. Sylhet is located at $24.8917^{\circ} \mathrm{N}$ and $91.8833^{\circ} \mathrm{E}$. It has 86074 units of house hold and total area $323.17 \mathrm{~km}^{2}$ [25]. This district is occupied by high proportion of ethnic minorities, stingy household condition, and poor road condition, no prohibition for preventive and curative measures.

*Corresponding author: Muhammed Hossain, Department of Parasitology, Faculty of Veterinary and Animal Sciences, Sylhet Agricultural University, Sylhet-3100, Bangladesh, Tel: 880167 306475; E-mail: bmhossain34sau@gmail.com

Received January 29, 2016; Accepted February 06, 2016; Published February 13, 2016

Citation: Hossain M, Alam MDS, Khair M, Sayeed MDA, Bhuiyan MJU (2016) Prevalence and Risk Factors of Strongyloides Stercoralis Infection in Selected Tea Garden of Sylhet, Bangladesh. J Trop Dis 4: 206. doi:10.4172/2329-891X.1000206

Copyright: (c) 2016 Hossain M, et al. This is an open-access article distributed under the terms of the Creative Commons Attribution License, which permits unrestricted use, distribution, and reproduction in any medium, provided the original author and source are credited. 


\section{Ethical Consideration}

Before commencement of the study, ethical clearance was obtained from the SAU Ethical Review Board. A consent form was provided to each study subject together with stool containers a day before the day of data collection. Parents were asked to sign the consent forms if they agreed on their children to be involved in the study.

\section{Data collection}

The study was conducted for a period of 12 months starting from June 2014 to May 2015. Before enrollment of the participants the verbal consent of the parents or legal guardians was taken. Data were collected by following structured questionnaire approved by ICDDR'B, Dhaka, Bangladesh.

\section{Collection of stool sample}

Supply and collection of stool pot: During each phase of study appropriately labeled plastic stool container for the collection of stool specimen was provided to the parents. The label of the stool pot had the subject's name, date of sample collection, identification number and the name of the areas. They were instructed on how to collect and put stool in the container at the toilet. The next day morning the stool pot collected directly from the participant's guardians with making proper questionnaire. The specimens were packed in a cool box with ice packs and transported by a vehicle to the Parasitology Laboratory, Sylhet Agricultural University, Faculty of Veterinary and Animal Science, Sylhet, Bangladesh and for molecular detection sent to parasitology laboratory of International Center for Diarrhoeal Disease Research Bangladesh (ICDDR'B), Dhaka, Bangladesh.

\section{Analysis of stool specimens}

Direct smear method and Harada mori culture: The stool samples collected from each participant were examined direct saline smear for the presence of parasitic eggs. The every stool sample were cultured at $25-28^{\circ} \mathrm{C}$ in incubator for ten days and examined from five days onward up to ten days to evaluate the presence of larvae in culture fluid [26]. Any sample shows positive either in direct smear or Harada mori culture was considered as positive sample. The extracted DNA from filariform larvae was used as control DNA for molecular analysis.

\section{Extraction of genomic DNA}

For the isolation of DNA from positive culture water, QIAGEN DNeasy Blood \& Tissue Kit (QIAGEN, Hilden, Germany) was used. The culture positive water was vortexed and centrifuged then diluted by filtered PBS. $200 \mu \mathrm{l}$ of sample was taken into $1.5 \mathrm{ml}$ micro-centrifuge tubes and $20 \mu \mathrm{l}$ Proteinase $\mathrm{K}$ was added. The tubes were vortexed by kept for incubation for $10 \mathrm{mins}$ at room temperature. $200 \mu \mathrm{l}$ of buffer ATL was added to the tubes and mixed well. The samples were incubated in a water bath at $56^{\circ} \mathrm{C}$ for 1 hour. $200 \mu \mathrm{l}$ of $100 \%$ Et-OH was added to the tubes. The samples were then transferred to the spin columns. The spin columns were centrifuged at $8,000 \mathrm{rpm}$ for $1 \mathrm{~min}$. Collection tubes were changed. $500 \mu \mathrm{l}$ of AW1 buffer was added to the columns. Again centrifuged at $8,000 \mathrm{rpm}$ for $1 \mathrm{~min}$. The liquid was removed from the collection tubes and placed back. $500 \mu \mathrm{l}$ of AW2 buffer was added to the columns. Centrifuged at $14,000 \mathrm{rpm}$ for $3 \mathrm{~min}$. The columns were placed in a fresh micro-centrifuge tube. $60 \mu \mathrm{l}$ of $\mathrm{AE}$ buffer (elution) was added. Centrifuged at 14,000 rpm for $2 \mathrm{~min}$. The columns were discarded and the DNA was ready.

\section{Conventional PCR}

Purified DNA template was used for amplification in a DNA

\begin{tabular}{|c|c|c|c|}
\hline Characteristics & Frequency & $\begin{array}{c}\text { Total no. of } \\
\text { sample }\end{array}$ & Percentage \\
\hline Participants Schooling & & 300 & \\
\hline Primary & 104 & & 34.67 \\
\hline Secondary & 16 & & 05.33 \\
\hline Not applicable & 180 & & 60.00 \\
\hline Mother's schooling & & 300 & 21.00 \\
\hline Primary & 63 & & 01.00 \\
\hline Secondary & 03 & & 78.00 \\
\hline Not applicable & 234 & & 28.67 \\
\hline Father's schooling & & 300 & 24.00 \\
\hline Primary & 86 & & 47.33 \\
\hline Secondary & 72 & & \\
\hline Not applicable & 142 & & \\
\hline
\end{tabular}

Table 1: Educational status of the participants and parents in tea garden community

\begin{tabular}{|c|c|c|c|}
\hline Level of occupation & Frequency & $\begin{array}{c}\text { Total no. of } \\
\text { sample }\end{array}$ & Percentage \\
\hline Father's occupation & & 300 & \\
\hline Unemployed & 11 & & 03.67 \\
\hline Day laborer & 182 & & 60.67 \\
\hline Service & 80 & & 26.67 \\
\hline Tea garden worker & 9 & & 03.00 \\
\hline Other & 18 & & 06.00 \\
\hline Mother's occupation & & 300 & \\
\hline Housewife & 167 & & 53.33 \\
\hline Service & 1 & & 00.33 \\
\hline Business & 132 & & 44.00 \\
\hline
\end{tabular}

Table 2: Occupational status of the parents in tea garden community.

thermal cycler using a species specific primer set as described by [27]. Positive and negative controls were systematically incorporated in each PCR run. Forward (SSF: 5'ATC GTG TCG GTG GAT CAT TC 3') and reverse (SSR: 5'CTA TTA GCG CCA TTT GCA TTC 3') primer pair was used and target $114 \mathrm{bp}$ gene. PCR reactions were performed using the following reaction mixture. $2 \mu \mathrm{l}$ of purified DNA template was used for the PCR with $3 \mu \mathrm{l}$ of each primer, $2.5 \mu \mathrm{l}$ of 10X Taq buffer (New England Biolabs Inc.), $0.5 \mu \mathrm{l}$ of $10 \mathrm{mM}$ dNTPs (GENE Mate), $2 \mu \mathrm{l}$ of $25 \mu \mathrm{M} \mathrm{MgCl}_{2}$ and $0.2 \mu \mathrm{l}$ of Taq DNA Polymerase (New England Biolabs Inc.) In total volume of $25 \mu \mathrm{l}$ reaction mixture. The cycle conditions for the PCR ( 40 cycles) step with an initial denaturation period of $5 \mathrm{~min}$ at $95^{\circ} \mathrm{C}$ were: denaturation at $95^{\circ} \mathrm{C}$ for $40 \mathrm{sec}$, annealing at $50^{\circ} \mathrm{C}$ for $40 \mathrm{sec}$, extension at $68^{\circ} \mathrm{C}$ for $20 \mathrm{sec}$ and final extension for $8 \mathrm{~min}$ to insure that all product were full-length. The amplified PCR products were analyzed immediately by electrophoresis on a $2.0 \%$ agarose gel (Sigma -Aldrich Inc., USA).

\section{Electrophoresis}

The amplified PCR products were analyzed immediately by electrophoresis on a $2.0 \%$ agarose gel (Sigma -Aldrich Inc., USA). The gel was stained with ethidium-bromide and visualized under UV transillumination (GelDoc ${ }^{\oplus}$, Biorad, USA). The sizes of the PCR products were estimated using 100 base pairs (bp) DNA ladder marker (SigmaAldrich Inc., USA).

\section{Statistical analysis}

Statistical analysis was performed by Logistic Regression procedure using STATA 13 (College Station, Texas 77845 USA) and the level of significance was considered as $\mathrm{P}<0.05$. In the univariable analysis, $\lambda^{2}$ test done for risk factors associated with infection status. In the multivariable logistic regressions, variables with a P-value of $\leq 0.20$ in 
Citation: Hossain M, Alam MDS, Khair M, Sayeed MDA, Bhuiyan MJU (2016) Prevalence and Risk Factors of Strongyloides Stercoralis Infection in Selected Tea Garden of Sylhet, Bangladesh. J Trop Dis 4: 206. doi:10.4172/2329-891X.1000206

Page 3 of 7

\begin{tabular}{|c|c|c|c|}
\hline $\begin{array}{l}\text { Other demographic } \\
\text { information }\end{array}$ & Frequency & $\begin{array}{l}\text { Total no. of } \\
\text { sample }\end{array}$ & Percentage \\
\hline Age group & & 300 & \\
\hline $0-10$ & 242 & & 80.67 \\
\hline $11-20$ & 19 & & 06.33 \\
\hline $21-30$ & 13 & & 04.33 \\
\hline $31-40$ & 12 & & 04.00 \\
\hline 41-up & 14 & & 04.67 \\
\hline Sex group & & 300 & \\
\hline Male & 177 & & 59.00 \\
\hline Female & 123 & & 41.00 \\
\hline Name of the areas & & 300 & \\
\hline Khadim tea estate & 47 & & 15.67 \\
\hline Burjan tea estate & 79 & & 26.33 \\
\hline Lakkatora tea estate & 65 & & 21.00 \\
\hline Malnichara tea esstate & 63 & & 21.67 \\
\hline Daldali tea estate & 46 & & 15.33 \\
\hline Category of weight $(\mathrm{kg})$ & & 300 & \\
\hline $0-20$ & 186 & & 62.00 \\
\hline $21-40$ & 65 & & 21.67 \\
\hline 41-up & 49 & & 16.33 \\
\hline Income of house & & 300 & \\
\hline$\leq 5000$ & 103 & & 34.33 \\
\hline$>5000$ & 197 & & 65.67 \\
\hline $\begin{array}{c}\text { No of People living in } \\
\text { house }\end{array}$ & & 300 & \\
\hline$\leq 4$ & 145 & & 48.33 \\
\hline$\geq 5$ & 155 & & 51.67 \\
\hline Name of the season & & 300 & \\
\hline Rainy & 65 & & 21.67 \\
\hline Winter & 116 & & 38.67 \\
\hline Summer & 119 & & 39.67 \\
\hline
\end{tabular}

Table 3: Other demographic information of tea garden community.

the univariable analysis were included as predictors. ORs and 95\% CI were reported. P-values $<0.05$ were regarded as significant.

\section{Results}

\section{Study participants}

Of 300 participants $59.00 \%$ male and $41.00 \%$ female were enrolled in this study out of five tea garden areas. Only $40.00 \%$ of the participants had primary education whereas majority of the participants $60.00 \%$ had not received primary education. The primary education completed possesses $10.56 \%$ (95\% CI 06.476-15.992) infection and illiterate participant's $15.83 \%$ (95\% CI 09.8102-23.616) infection.

\section{Prevalence of S. stercoralis infection}

Of 300 tested sample only 38 cases found positive with S. stercoralis infection. The prevalence of strongyloidiasis is decreasing with the increase of ages though there is increase in the age group 21-30 years. From all ages group prevalence was higher in female $13.82 \%(95 \%$ CI $08.262-21.204)$ than male $11.86 \%$ (95\% CI 07.496-17.562) with S. stercoralis infection.

Foot ware is a factor for S. stercoralis infection because having no foot ware showing higher prevalence than having foot ware. The prevalence is higher in winter season $18.97 \%$ (95\% CI 12.283-27.293) than rainy $15.38 \%$ (95\% CI $07.632-26.478)$ and summer $05.04 \%(95 \%$ CI 01.872-10.651). The crowd house have higher rate of infection than small family (Tables 1- 4).

Overall, in examination by conventional PCR, 38 out of 300 stool

\begin{tabular}{|c|c|c|c|}
\hline Points & $\begin{array}{c}\text { Total no. of } \\
\text { tested }\end{array}$ & $\begin{array}{l}\text { Total no. of } \\
\text { positive }\end{array}$ & $\begin{array}{c}\text { Prevalence }(95 \% \\
\text { confidence Intervals) }\end{array}$ \\
\hline \multicolumn{4}{|l|}{ Season } \\
\hline Rainy & 65 & 10 & $15.38(07.632-26.478)$ \\
\hline Winter & 116 & 22 & $18.97(12.283-27.293)$ \\
\hline Summer & 119 & 06 & $05.04(01.872-10.651)$ \\
\hline \multicolumn{4}{|l|}{ Age } \\
\hline$\leq 10$ & 242 & 32 & $13.22(09.223-18.151)$ \\
\hline $11-20$ & 19 & 01 & $05.26(00.133-26.028)$ \\
\hline $21-30$ & 13 & 02 & $15.38(01.920-45.447)$ \\
\hline $31-40$ & 12 & 01 & $08.33(00.210-38.479)$ \\
\hline$\geq 41$ & 14 & 02 & $14.29(01.779-42.812)$ \\
\hline \multicolumn{4}{|l|}{ Areas } \\
\hline Khadim tea estate & 47 & 12 & $25.53(13.944-40.349)$ \\
\hline Burjan tea estate & 79 & 13 & $16.46(09.063-26.494)$ \\
\hline Lakkatora tea estate & 65 & 05 & $07.69(02.544-17.045)$ \\
\hline Malnichara tea estate & 63 & 08 & $12.69(05.645-23.496)$ \\
\hline Daldali tea estate & 46 & - & - \\
\hline \multicolumn{4}{|l|}{ Sex } \\
\hline Male & 177 & 21 & $11.86(07.496-17.562)$ \\
\hline Female & 123 & 17 & $13.82(08.262-21.204)$ \\
\hline \multicolumn{4}{|l|}{ People in house } \\
\hline$\leq 4$ & 127 & 18 & $14.17(08.621-21.471)$ \\
\hline$\geq 5$ & 135 & 20 & $14.81(09.290-21.948)$ \\
\hline \multicolumn{4}{|l|}{ Have foot ware } \\
\hline No & 05 & 02 & $40.00(05.274-85.336)$ \\
\hline Yes & 257 & 36 & $14.01(10.007-18.862)$ \\
\hline \multicolumn{4}{|l|}{ Work in bare foot } \\
\hline No & 48 & 07 & $14.58(06.070-27.764)$ \\
\hline Yes & 214 & 31 & $14.49(10.059-19.927)$ \\
\hline
\end{tabular}

Table 4: Prevalence of Strongyloides stercoralis infection in tea garden community.

samples were found positive for S. stercoralis where by Harada mori culture for the same samples the detected positive cases was 18 (Table 5).

\section{Risk factor assessment for $S$. stercoralis infection}

The study participants corresponding data were analyzed by $\lambda^{2}$ test for univariable analysis and found several factors significantly associated with strongyloidiasis infection. The climatic factors such as season $(\mathrm{P}=0.004)$ and areas $(\mathrm{P}=0.003)$ were significantly associated.

Other factors such as periodic anthelmintic therapy, monthly family income, rubbing hand after toilet, toilet floor and using shoes in toilet are contributing tools for strongyloidiasis infection (Table 6). On the other hand sex, fathers occupation, household floor, disposal of stool, use of disinfectant cleaning toilet, possession of foot ware and working in bare foot are not significantly associated with Strongyloidiasis infection (Table 7).

\section{Discussion}

Of three hundred stool samples of tea garden community of

\begin{tabular}{|c|c|c|c|c|}
\hline \multicolumn{2}{|c|}{ Name of the test } & \multicolumn{2}{|c|}{ Harada mori Culture } & \multirow[t]{2}{*}{ Total } \\
\hline & & Positive & Negative & \\
\hline \multirow{2}{*}{$\begin{array}{l}\text { Conventional } \\
\text { PCR }\end{array}$} & Positive & 12 & 26 & 38 \\
\hline & Negative & 6 & 256 & 262 \\
\hline \multicolumn{2}{|c|}{ Total } & 18 & 282 & 300 \\
\hline
\end{tabular}

Pearson chi $\left(\lambda^{2}\right)$ test done and $\mathrm{P}<0.001$

Table 5: Comparison of the results of conventional PCR and Harada mori culture examinations for detection of Strongyloides stercoralis infection in single stool samples. 
Citation: Hossain M, Alam MDS, Khair M, Sayeed MDA, Bhuiyan MJU (2016) Prevalence and Risk Factors of Strongyloides Stercoralis Infection in Selected Tea Garden of Sylhet, Bangladesh. J Trop Dis 4: 206. doi:10.4172/2329-891X.1000206

Page 4 of 7

\begin{tabular}{|c|c|c|c|}
\hline Characteristics & $\begin{array}{l}\text { Positive } \\
\text { n=38 (\%) }\end{array}$ & $\begin{array}{l}\text { Negative } \\
n=262(\%)\end{array}$ & P-value \\
\hline \multicolumn{4}{|l|}{ Season } \\
\hline Rainy & $10(15.38)$ & $55(84.62)$ & \\
\hline Winter & $22(18.97)$ & $94(81.03)$ & \\
\hline Summer & $06(05.04)$ & $113(94.96)$ & 0.004 \\
\hline \multicolumn{4}{|l|}{ Areas } \\
\hline Khadim tea estate & $12(25.53)$ & $35(74.47)$ & \\
\hline Burjan tea estate & $13(16.46)$ & $66(83.54)$ & \\
\hline Lakkatora tea estate & $05(07.69)$ & $60(92.31)$ & \\
\hline Malnichara tea esstate & $08(12.70)$ & $55(87.30)$ & \\
\hline Daldali tea estate & 0.00 & $46(100.0)$ & 0.003 \\
\hline \multicolumn{4}{|l|}{ Sex } \\
\hline Male & $21(11.86)$ & $156(88.14)$ & \\
\hline Female & $17(13.82)$ & $106(86.18)$ & 0.616 (NS) \\
\hline \multicolumn{4}{|l|}{ Weight } \\
\hline$<10$ & $21(11.29)$ & $165(88.71)$ & \\
\hline $11-20$ & $11(16.92)$ & $54(83.08)$ & \\
\hline$>21$ & $06(12.24)$ & $43(87.76)$ & 0.449 (NS) \\
\hline \multicolumn{4}{|l|}{ Participant's schooling } \\
\hline Not applicable & $19(15.83)$ & $101(84.17)$ & \\
\hline Primary & $19(10.56)$ & $161(89.44)$ & 0.050 \\
\hline \multicolumn{4}{|l|}{ Father's occupation } \\
\hline Unemployed & $02(18.18)$ & $09(81.82)$ & \\
\hline Day laborer & $24(13.19)$ & $158(86.81)$ & \\
\hline Service & $05(06.25)$ & $75(93.75)$ & \\
\hline Tea garden worker & $02(22.22)$ & $07(77.78)$ & \\
\hline Other & $05(27.78)$ & $13(72.22)$ & 0.100 (NS) \\
\hline \multicolumn{4}{|l|}{ How many time pass stool } \\
\hline Two & $22(26.83)$ & $60(73.17)$ & \\
\hline One & $16(07.34)$ & $202(92.66)$ & $<0.001^{\star \star *}$ \\
\hline \multicolumn{4}{|l|}{ Monthly family income } \\
\hline$\leq 5000$ & $19(18.45)$ & $84(81.55)$ & \\
\hline$>5000$ & $19(09.64)$ & $178(90.36)$ & 0.030 \\
\hline \multicolumn{4}{|l|}{ Receive treatment } \\
\hline No & $26(20.80)$ & $99(79.20)$ & \\
\hline Yes & $12(06.86)$ & $163(93.14)$ & $<0.001^{* * *}$ \\
\hline \multicolumn{4}{|l|}{ Treatment 4 month interval } \\
\hline No & $34(19.43)$ & $141(80.57)$ & \\
\hline Yes & $04(03.20)$ & $121(96.80)$ & $<0.001^{* * *}$ \\
\hline \multicolumn{4}{|l|}{ Household floor } \\
\hline Mud & $38(13.82)$ & $237(86.18)$ & \\
\hline Semi-cemented & 0.00 & $24(100.0)$ & \\
\hline Cemented & 0.00 & $01(100.0)$ & 0.138 (NS) \\
\hline \multicolumn{4}{|l|}{ Toilet floor } \\
\hline Mud & $20(09.95)$ & $181(90.05)$ & \\
\hline Bamboo & $18(18.18)$ & $81(81.82)$ & 0.044 \\
\hline \multicolumn{4}{|l|}{ Where dispose stool } \\
\hline Around house & $24(11.37)$ & $187(88.63)$ & \\
\hline Jungle/Tea garden & $14(15.73)$ & $75(84.27)$ & 0.300 (NS) \\
\hline \multicolumn{4}{|l|}{ Rub hand after toilet } \\
\hline No & $28(10.94)$ & $228(89.06)$ & \\
\hline Yes & $10(22.73)$ & $34(77.27)$ & 0.030 \\
\hline \multicolumn{4}{|l|}{ Material for rubbing hand } \\
\hline Soap & $01(25.00)$ & $03(75.00)$ & \\
\hline Ash & $12(19.35)$ & $50(80.65)$ & \\
\hline Soil & $15(07.89)$ & $175(92.11)$ & \\
\hline other & $10(22.73)$ & $34(77.27)$ & 0.012 \\
\hline \multicolumn{4}{|c|}{ Use disinfectant toilet cleaning } \\
\hline No & $13(56.76)$ & $61(43.24)$ & \\
\hline Yes & $29(36.73)$ & $197(63.27)$ & 0.308 (NS) \\
\hline
\end{tabular}


Citation: Hossain M, Alam MDS, Khair M, Sayeed MDA, Bhuiyan MJU (2016) Prevalence and Risk Factors of Strongyloides Stercoralis Infection in Selected Tea Garden of Sylhet, Bangladesh. J Trop Dis 4: 206. doi:10.4172/2329-891X.1000206

Page 5 of 7

\begin{tabular}{|c|c|c|c|}
\hline Type of material wash & & & \\
\hline Soil & $13(22.41)$ & $35(74.47)$ & \\
\hline Ash & $13(06.67)$ & $182(93.33)$ & \\
\hline Soap & $12(25.53)$ & $45(77.59)$ & $<0.001^{\star \star *}$ \\
\hline \multicolumn{4}{|c|}{ Wash feet using toilet } \\
\hline Never & $30(14.25)$ & $182(85.85)$ & \\
\hline Not always & $04(05.13)$ & $74(94.87)$ & \\
\hline Always & $04(40.00)$ & $06(60.00)$ & 0.004 \\
\hline \multicolumn{4}{|c|}{ Have foot ware } \\
\hline No & $02(28.57)$ & $05(71.43)$ & \\
\hline Yes & $36(12.29)$ & $257(87.71)$ & 0.200 (NS) \\
\hline \multicolumn{4}{|c|}{ Use shoe going to school } \\
\hline Never & $22(10.58)$ & $186(89.42)$ & \\
\hline Rarely & $12(27.27)$ & $32(72.73)$ & \\
\hline Most time & $04(08.33)$ & $44(91.67)$ & 0.005 \\
\hline \multicolumn{4}{|c|}{ Work in bare foot } \\
\hline No & $07(12.73)$ & $48(87.27)$ & \\
\hline yes & $31(12.65)$ & $214(87.35)$ & 0.988 (NS) \\
\hline \multicolumn{4}{|c|}{ Wash feet coming from out } \\
\hline Not always & $22(17.19)$ & $106(82.81)$ & \\
\hline Always & $16(09.30)$ & $156(90.70)$ & 0.042 \\
\hline
\end{tabular}

${ }^{*+*}$ Highly significant $(P<0.05), N S=$ Not significant

Table 6: Invariable analysis of the factors associated with Strongyloides stercoralis infection in tea garden community of Sylhet.

\begin{tabular}{|c|c|c|}
\hline Name of the variable & Odds ratio (95\% Confidence Intervals) & P-value \\
\hline \multicolumn{3}{|l|}{ Season } \\
\hline Rainy & $3.424(1.183-9.905)$ & 0.023 \\
\hline Winter & $4.407(1.716-11.320)$ & \\
\hline Summer & 1 & \\
\hline \multicolumn{3}{|l|}{ Participants Schooling } \\
\hline Not applicable & $2.923(1.096-7.793)$ & 0.032 \\
\hline Primary & 1 & \\
\hline \multicolumn{3}{|l|}{ Income } \\
\hline$\leq 5000$ & $2.540(0.970-6.649)$ & 0.051 \\
\hline$\geq 5000$ & 1 & \\
\hline \multicolumn{3}{|l|}{ Receive anthelmintics } \\
\hline No & $3.946(1.369-11.375)$ & 0.011 \\
\hline Yes & 1 & \\
\hline \multicolumn{3}{|c|}{ Receive anthelmintic 4 month interval } \\
\hline No & $3.812(1.079-13.464)$ & 0.038 \\
\hline Yes & 1 & \\
\hline \multicolumn{3}{|l|}{ Toilet floor } \\
\hline Mud & $2.710(1.035-7.101)$ & 0.042 \\
\hline Bamboo & 1 & \\
\hline \multicolumn{3}{|c|}{ How many time pass stool a day } \\
\hline Two & $3.645(1.385-9.593)$ & 0.009 \\
\hline One & 1 & \\
\hline \multicolumn{3}{|l|}{ Wash feet using toilet } \\
\hline Never & $12.33(2.449-62.100)$ & 0.043 \\
\hline Not always & $3.049(1.038-8.959)$ & \\
\hline Always & 1 & \\
\hline Type of material washing ha & & \\
\hline
\end{tabular}




\begin{tabular}{|r|c|}
\hline Soil & $3.431(1.422-8.276)$ \\
\hline Ash & $02.80(1.231-6.367)$ \\
\hline Soap & 1 \\
\hline Going to School & \\
\hline Never & $5.556(1.959-15.753)$ \\
\hline Rarely & $5.000(0.937-26.683)$ \\
\hline Most time & 1 \\
\hline Wash feet coming from out & $<0.001^{+*+}$ \\
\hline Not always & $5.158(1.656-16.068)$ \\
\hline Always & 1 \\
\hline
\end{tabular}

Highly significant $(P<0.05)$, OR= Odds Ratio, $\mathrm{Cl}=$ Confidence Interval

Table 7: Multivariable analysis of Strongyloides stercoralis infection in Tea garden community of Sylhet.

Sylhet were screened by Harada mori Culture and Conventional PCR found prevalence of $S$. stercoralis infection by copro culture $06.00 \%$ (95\% CI 03.83-09.28) and conventional PCR 12.67\% (95\% CI 09.3716.91) which is almost double than copro culture. These reports have coherence with $[28,29]$ but contracted with recent study in Dhaka City [10]. The difference of the infection rate is also statistically significant. The previous reports from Thailand revealed that the prevalence of $S$. stercoralis infection varied widely and ranging between $07.60 \%$ and $30.30 \%[10,30,31]$. This is the first time study on Strongyloidiases in tea garden community of Sylhet and there is paucity of information about it. The present study showed female (13.82\%) participants have higher prevalence of $S$. stercoralis infection than male (11.86\%) which is also supported by [32]. The winter season disclosed highest percentage of infection whereas rainy stood second and summer stood lowest infection. This variation of infection might be due to the environmental factors stimulating development of the parasitic larvae. The Khadimnagar Tea garden's hygienic condition was very poor compared to other tea garden and its parasitic load were highest but one novel findings of our study is Daladali tea garden is free from $S$. stercoralis infection.

The elderly persons had higher prevalence than the young participants in our study which is supported by another study in Cambodia [11].

The risk factors of strongyloidiasis increased with illiteracy $\mathrm{OR}=$ $2.923(95 \%$ CI $1.096-7.793, \mathrm{P}=0.032$ ) which is similar to the finding of [32] in Ethiopia. The climatic factor such as rainy season $\mathrm{OR}=3.424(95 \%$ CI 1.183-9.905, $\mathrm{P}=0.023$ ) associated with infection than other season. Periodic anthelmintic taking reduces the infection rate but when break in the chemotherapy of four month interval occurs then high rate of infection $\mathrm{OR}=3.812(95 \% \mathrm{CI} 1.079-13.464, \mathrm{P}=0.038)$ revealed. The family income significantly associated with Strongyloidiases infection because the low income family gets more infection owing to their poor family status and unable to keep them in hygienic condition. One study in elderly of Brazil Showed significantly association of family income with Strongyloidises infection [33].

Personal hygiene wash feet using toilet, coming from out significantly associated with Strongyloidiasis infection. Types of material for washing hand significantly contribute to the infection, use of soil 3.431 fold (1.422-8.276), use of ash 2.8 fold (1.231-6.367) risk for S. stercoralis infection. Muddy toilet floor $\mathrm{OR}=2.710(95 \% \mathrm{CI}$ 1.035-7.101, $\mathrm{P}=0.042$ ) contribute times higher strongyloidiases than Bamboo floor because the muddy floor provides suitable condition for the development of the infective larvae. When these infective larvae get contact with the intact skin then penetrate the skin initiate its infection in the host body. Washing practices of feet coming from out was important factors for Strongyloidases infection, the participants who did not washed feet get infection $\mathrm{OR}=5.158(95 \%$ CI $1.656-16.068$, $\mathrm{P}=0.005$.

The lack of correlation between copro-culture and Molecular techniques for detection of S. stercoralis infection in our study population might indicate that the two methods are detecting different percentages of infected individuals. Those who were not detected positive by copro-culture showed positive in molecular techniques. There were 18 samples positive in copro-culture and 38 samples were positive in molecular techniques. Nevertheless, our study shows that $S$. stercoralis infection remains prevalent in Bangladesh particularly in tea garden community.

\section{Conclusion}

We can conclude that $\mathrm{S}$. stercoralis infection was highly prevalent in the tea garden community of Sylhet and it does not depend on whether the individual was institutionalized or not. Therefore early diagnosis through specific methods is warranted in asymptomatic elderly in order to prevent the risk of hyper-infection or disseminated infection, thus avoiding high mortality.

\section{Acknowledgements}

The Authors thankful to International Center for Diarrhoeal Disease Research Bangladesh (ICDDR'B), Dhaka, Bangladesh for their logistic supports and providing laboratory facilities. We also thank the Department of Parasitology, Sylhet Agricultural University, Sylhet. We also acknowledge the contribution of the study participants.

\section{References}

1. Bethony J, Brooker S, Albonico M, Geiger SM, Loukas A, et al. (2006) Soiltransmitted helminth infections: ascariasis, trichuriasis, and hookworm. Lancet 367: 1521-1532.

2. Olsen A, van Lieshout L, Marti H, Polderman T, Polman K, et al (2009) Strongyloidiasis-the most neglected of the neglected tropical diseases? Trans R Soc Trop Med Hyg 103: 967-972.

3. Vadlamudi RS, Chi DS, Krishnaswamy G (2006) Intestinal strongyloidiasis and hyperinfection syndrome. Clin Mol Allergy 4: 8.

4. Marcos LA, Terashima A, Dupont HL, Gotuzzo E (2008) Strongyloides hyperinfection syndrome: an emerging global infectious disease. Trans $\mathrm{R}$ Soc Trop Med Hyg 102: 314-318.

5. Basile A, Simzar S, Bentow J, Antelo F, Shitabata P, et al. (2010) Disseminated Strongyloides stercoralis: hyperinfection during medical immunosuppression. J Am Acad Dermatol 63: 896-902. 
Citation: Hossain M, Alam MDS, Khair M, Sayeed MDA, Bhuiyan MJU (2016) Prevalence and Risk Factors of Strongyloides Stercoralis Infection in Selected Tea Garden of Sylhet, Bangladesh. J Trop Dis 4: 206. doi:10.4172/2329-891X.1000206

6. Hall A, Conway DJ, Anwar KS, Rahman ML (1994) Strongyloides stercoralis in an urban slum community in Bangladesh: factors independently associated with infection. Trans R Soc Trop Med Hyg 88: 527-530.

7. Adedayo O, Grell G, Bellot $P$ (2002) Hyperinfective strongyloidiasis in the medical ward: review of 27 cases in 5 years. South Med J 95: 711-716.

8. Siddiqui AA, Berk SL (2001) Diagnosis of Strongyloides stercoralis infection. Clin Infect Dis 33: 1040-1047.

9. Segarra-Newnham M (2007) Manifestations, diagnosis, and treatment of Strongyloides stercoralis infection. Ann Pharmacother 41: 1992-2001.

10. Sultana Y, Gilbert GL, Ahmed BN, Lee R (2012) Strongyloidiasis in a high risk community of Dhaka, Bangladesh. Trans R Soc Trop Med Hyg 106: 756-762.

11. Khieu V, Schär F, Marti H, Sayasone S, Duong S, et al. (2013) Diagnosis treatment and risk factors of Strongyloides stercoralis in schoolchildren in Cambodia. PLoS Negl Trop Dis 7: e2035.

12. Repetto SA, Durán PA, Lasala MB, González-Cappa SM (2010) High rate of strongyloidosis infection, out of endemic area, in patients with eosinophilia and without risk of exogenous reinfections. Am J Trop Med Hyg 82: 1088-1093.

13. Koga-Kita K (2004) Intestinal parasitic infections and socioeconomic status in Prek Russey Commune, Cambodia. Nihon Koshu Eisei Zasshi 51: 986-992.

14. Longfils $P$, Heang UK, Soeng $H$, Sinuon M (2005) Weekly iron and folic acid supplementation as a tool to reduce anemia among primary school children in Cambodia. Nutr Rev 63: S139-145.

15. Gutierrez Y (2000) Diagnostic pathology of parasitic infections with clinical correlations. (2ndedn), Oxford University Press, New York.

16. Garcia LS (2010) Clinical microbiology procedures handbook. (3rdedn) American Society for Microbiology.

17. Knopp S, Mgeni AF, Khamis IS, Steinmann P, Stothard JR, et al. (2008) Diagnosis of soil-transmitted helminths in the era of preventive chemotherapy: effect of multiple stool sampling and use of different diagnostic techniques. PLoS Negl Trop Dis 2: e331.

18. Foreman EB, Abraham PJ, Garland JL (2006) Not your typical strongyloides infection: a literature review and case study. South Med J 99: 847-852.

19. Fardet L, Généreau T, Poirot JL, Guidet B, Kettaneh A, et al. (2007) Severe strongyloidiasis in corticosteroid-treated patients: case series and literature review. J Infect 54: 18-27.
20. Cruz RJ, Vincenzi R, Ketzer BM (2010) Duodenal obstruction - an unusua presentation of Strongyloides stercoralis enteritis: a case report. World J Emerg Surg 5: 23.

21. Grove DI (1996) Human strongyloidiasis. Adv Parasitol 38: 251-309.

22. Lim S, Katz K, Krajden S, Fuksa M, Keystone JS, et al. (2004) Complicated and fatal Strongyloides infection in Canadians: risk factors, diagnosis and management. CMAJ 171: 479-484.

23. Ly MN, Bethel SL, Usmani AS, Lambert DR (2003) Cutaneous Strongyloides stercoralis infection: an unusual presentation. J Am Acad Dermatol 49: S157160

24. Hall A, Anwar KS, Tomkins AM (1992) Intensity of reinfection with Ascaris lumbricoides and its implications for parasite control. Lancet 339: 1253-1257.

25. http://www.banglapedia.org/

26. Harada Y, Mori O (1955) A new method for culturing hookworm. Yonago Acta Med 1: 177-179.

27. Moghaddassani H, Mirhendi H, Hosseini M, Rokni M, Mowlavi G, et al. (2011) Molecular diagnosis of Strongyloides stercoralis infection by PCR detection of specific DNA in human stool samples. Iran J Parasitol 6: 23.

28. Marchi Blatt J, Cantos GA (2003) Evaluation of techniques for the diagnosis of Strongyloides stercoralis in human immunodeficiency virus (HIV) positive and HIV negative individuals in the city of Itajai, Brazil. Braz J Infect Dis 7: 402-408.

29. Steinmann P, Zhou XN, Du ZW, Jiang JY, Wang LB, et al. (2007) Occurrence of Strongyloides stercoralis in Yunnan Province, China, and comparison of diagnostic methods. PLoS Negl Trop Dis 1: e75

30. Wongsaroj T, Phatihatakorn W, Ramasoota P, Anamnart W, Kaewpoonsri N, et al. (2010) Epidemiological study of strongyloidiasis in Southern Thailand, 2007 J Trop Med Parasitol 31: 6-13.

31. Sithithaworn P, Srisawangwong T, Tesana S, Daenseekaew W, Sithithaworn J, et al. (2003) Epidemiology of Strongyloides stercoralis in north-east Thailand: application of the agar plate culture technique compared with the enzymelinked immunosorbent assay. Trans R Soc Trop Med Hyg 97: 398-402.

32. Mekonnen B, Erko B, Legesse M (2014) Prevalence of Intestinal Parasitic Infections and Related Risk Factors among Street Dwellers in Addis Ababa Ethiopia. J Trop Dis 2: 2

33. Naves MM, Costa-Cruz JM (2013) High prevalence of Strongyloides stercoralis infection among the elderly in Brazil. Rev Inst Med Trop Sao Paulo 55: 309-313. 